\title{
Screening of Endophyte Piper betle Bacteria from the Forests of HPPB University Andalas as Antibiotics Producer
}

\author{
Anthoni Agustien ${ }^{1 *}$, Putra Santoso ${ }^{1}$, Nespy Permata Sari ${ }^{1}$, Fathya Annisa ${ }^{1}$, \\ Nasril Nasir ${ }^{1}$, Yetria Rilda ${ }^{2}$ and Akmal Djamaan ${ }^{3}$ \\ ${ }^{1}$ Department of Biology, ${ }^{2}$ Department of Chemistry, ${ }^{3}$ Faculty of Pharmacy, Andalas University, \\ Kampus Limau, Padang, Indonesia \\ *Corresponding author
}

\section{A B S T R A C T}

\begin{tabular}{|c|c|}
\hline $\begin{array}{l}\text { K e y w o r d s } \\
\text { Screening, } \\
\text { Endophytic } \\
\text { bacteria, } P \text {. betle, } \\
\text { Antibiotics, } \\
\text { Inhibitory zone. }\end{array}$ & $\begin{array}{l}\text { Today livelihood exploration of endophytic microorganisms as a new source of antibiotics } \\
\text { is very intensive, especially from medicinal plants. Piper betle, a green betel plant, is a } \\
\text { medicinal plant. So that bacterial isolates from Piper betle are likely to produce } \\
\text { antibacterial compounds. This study aims to screen the endophytic bacteria of green betel } \\
\text { plants that live wild in HPPB forest, Andalas University. The leaf sampling was done by } \\
\text { purposive random sampling, bacterial isolation was done by spread plate method on tryptic } \\
\text { soy agar (TSA). Screening of antibiotic-producing endophytic bacteria was done by paper }\end{array}$ \\
\hline Article Info & \\
\hline $\begin{array}{l}\text { Accepted: } \\
28 \text { October } 2017 \\
\text { Available Online: } \\
10 \text { December } 2017\end{array}$ & $\begin{array}{l}\text { isolates with six isolates having antibiotic activity against } E \text {. coli and } S \text {. aureus test } \\
\text { bacteria; one isolate was only active against } E \text {. coli alone and four isolates were only } \\
\text { active against } S \text {. aureus. Endophytic bacterial, isolates BES-2 has the largest inhibitory } \\
\text { zone diameter }(18.58 \mathrm{~mm}) \text { and includes strong category antibiotics. }\end{array}$ \\
\hline
\end{tabular}

\section{Introduction}

Betel plants is one type of medicine from nature that can be used as an alternative as an antiseptic, without side effects. The betel extract contains several active components that have antibacterial activity, such as safrol and kavibetol acetate (Arambewela et al., 2005). Green betel extract fractions have antibacterial activity (Hoque et al., 2011) and antifungals of the genus Aspergillus and Candida (Ali et al., 2010). Endophytes isolated from betel plants are highly potential for the livelihood of new natural products. In theory, endophytic microbes isolated from a plant can produce secondary metabolites similar to those of original plants or even in relatively high numbers (Radji, 2005). In addition, the advantages of endophytic microbes are short life cycle and secondary metabolites can be produced on a large scale, therefore endophytic microbes have good prospects in the discovery of new compounds one of them as antibiotic producers (Strobel and Daisy, 2003). As host plants, the endemic plants in the subtropical or tropical regions are particularly important because of their richness in species. Utilization of endophytic bacteria to produce bioactive compounds has several advantages such as can be produced in 
large scale, possibly obtained new bioactive compounds with different characteristics (Tanaka et al., 1999).

The HPPB forest area of Andalas University has many types of wild life wild betel which is generally dominated by $P$. betle green betel. This allows the discovery of different betel endinocytes from different endophytes, due to environmental factors such as climate, nutrients and location, a factor that greatly determines the diversity of green betel endophytic microbes. The high diversity of high endophytic microbial diversity, also predicted to be found in various antibiotics and the possibility of finding new antibiotic compounds is very large. This study aims to obtain bacterial endophytic bacterial isolates of green betel plants in HPPB forest areas, Andalas University antibiotic producer.

\section{Materials and Methods}

\section{Collection of leaf samples from betel plants}

Leaf sampling from wild green betel plant was conducted by purposive random sampling method from four locations in HPPB Unand forest area (Fig. 1). Healthy leaf samples, not young leaves or old leaves, each taken ten pieces of betel leaf from each clump. Leaf collecting from plants refers to Melo et al., (2009) that has been modified, the leaves to be collected are cut with a sterile knife then washed with sterile distilled water, then the green betel leaf is placed in a plastic bag and placed in a cooler. Leaves of plants that have been collected immediately brought to the laboratory.

\section{Sterilization of leafy plants leaf surface}

Plant leaf samples that have been collected, cut approximately $1 \mathrm{~cm} 2$. The leaves were then disinfected with $70 \%$ ethanol for 1 minute, then immersed with $2 \%$ sodium hypochloride for 1 minute, then fed into a container containing $70 \%$ ethanol and incubated for 30 seconds to remove sodium hypochloride and last washed with three sterile distilled water time.

\section{Isolation and purification of endophytic bacteria}

The sterile plant segment was finely sliced and then fed into $0.85 \%$ physiologic $\mathrm{NaCl}$ solution and homogenized, after homogeneous then $0.1 \mathrm{ml}$ of the solution was inoculated in a spread plate on Petridish containing TSA medium containing benomyl fungicide of $1 \mu \mathrm{L} \mathrm{mL}{ }^{-1}$. It was then incubated at room temperature for 76 hours. Different bacterial colonies were inoculated on a Nutrient Agar medium streak plate and incubated for 24 hours at room temperature. Single colonies are inoculated on slant agar and labeled.

\section{Screening of endophytic bacteria of green betel producing antibiotics}

Screening of endophytic bacteria of betelproducing plant antibiotics is done by means of income stages and antibiotic isolation according to Djamaan et al., (2012) that has been modified. Prepared medium for the production of inoculum and antibiotic production with formula in every $1 \mathrm{~L}: 30 \mathrm{ml}$ of soaking water corn, $30 \mathrm{~g}$ sucrose, $5 \mathrm{~g}$ $\mathrm{CaCO}_{3}, 2 \mathrm{~g} \mathrm{MgSO}_{4}, 1 \mathrm{~g} \mathrm{FeSO}_{4}$ and $0.1 \mathrm{~g}$ $\mathrm{ZnSO}_{4}$ with sterile $\mathrm{pH} 7.4$ in Erlenmeyer. Rejuvenated endophytic bacterial isolates were each administered 1-2 ose in Erlenmeyer containing $50 \mathrm{~mL}$ of medium. Bacterial culture was incubated at room temperature, $150 \mathrm{rpm}$ for 24 hours. A $1 \mathrm{ml}$ bacterial culture was inoculated on Erlenmeyer containing 100 $\mathrm{mL}$ of antibiotic production medium. The culture was incubated at room temperature, at $150 \mathrm{rpm}$ for 48 hours. Bacterial culture was centrifuged at $5000 \mathrm{rpm}$ for $15 \mathrm{~min}$. The 
supernatant obtained was a crude extract of antibiotics to further test its antibiotic activity.

\section{Testing of antibiotics from endophytic bacteria in vitro}

Testing of antibiotic activity of each endophytic bacterial was done by paper disc method. The disc paper is made by gluing 3 layers of Whatman no. 42, then perforated with a piercing paper to obtain discs with diameter of $6 \mathrm{~mm}$, sterilized by autoclave. Poured $15 \mathrm{ml}$ medium NA on Petridish. Furthermore, each medium in a petri dish was applied to E. coli and S. aureus test bacteria. The disc paper is immersed in a crude antibiotic solution of each endophytic bacterial isolate, then aseptically the disc paper is removed in a sterile container and waited until dry. Aseptic disc paper is placed on a NA medium that has been applied with test bacteria. Subsequently incubated at room temperature for 24-48 hours. The diameter of the barrier formed around the disc paper is measured with the help of the slide term. Endophytic bacteria indicate antibiotic producers if clear zone is formed around the disc paper. Records of endophytic bacterial isolates may produce antibiotics along with the inhibitory zone diameter.

\section{Results and Discussion}

Isolation of endophytic bacteria from wild green betel plants that live in HPPB forest using TSA medium, obtained by bacteria colony isolate endofitik. Endophytic bacterial isolates generally have moderate growth rates ie at 48 hours of incubation with a variety of colonial morphological characteristics such as shape, color, edges, colony elevation. This means that TSA medium can be used as a medium to isolate endophytic bacteria of wild betel plant that live wild in forest area, while Nutrient agar medium can be used as a medium for purification of endophytic bacteria. Endophytic bacterial characteristics generally grow in isolation medium after two days of incubation (Jalgaonwala et al., 2010). The presence of endophytic bacteria in plants with a high diversity of colonies indicates that the environmental factors in which green betel plants are alive and evolved have a very important role, this is because HPPB forest area of Andalas University is including tropical rain forest with high moisture and forest land covered by litter that is thick enough to contain nutrients and minerals that are ideal for growth and development for soil microorganisms, including bacteria.

Endophytic bacteria originating from the environment around the plant such as the area of rhizosphere and plant philosphere capable of penetrating into the plant tissue through stomata, lentikula or area of the emergence of lateral roots that cause the difference of the type of endophytic bacteria obtained and secondary metabolites it produces (Mano and Morasaki, 2008). Endophytic bacteria live in the vascular vessels or in the intercellular space, entering into the plant tissue in general through the roots, but also through the leaf stomata (Zinniel et al., 2002).

The results of screening of eighty six green betel endophytic isolates showed that eleven bacterial isolates indicated antibiotics, indicated by the inhibition zone of $E$. coli and $S$. aureus test bacteria, while seventy-five other endophytic bacterial isolates were likely to have other roles in betel plants or have the ability to produce the same secondary metabolites as those of green betel plants such as chemical compounds that have antimalarial activity, inhibitory agents against xanthine oxidase, anti-clotting or bacterial isolates each have the ability to produce other expressed secondary metabolites of the gene that had existed in the bacterial cell (Fig. 2). 


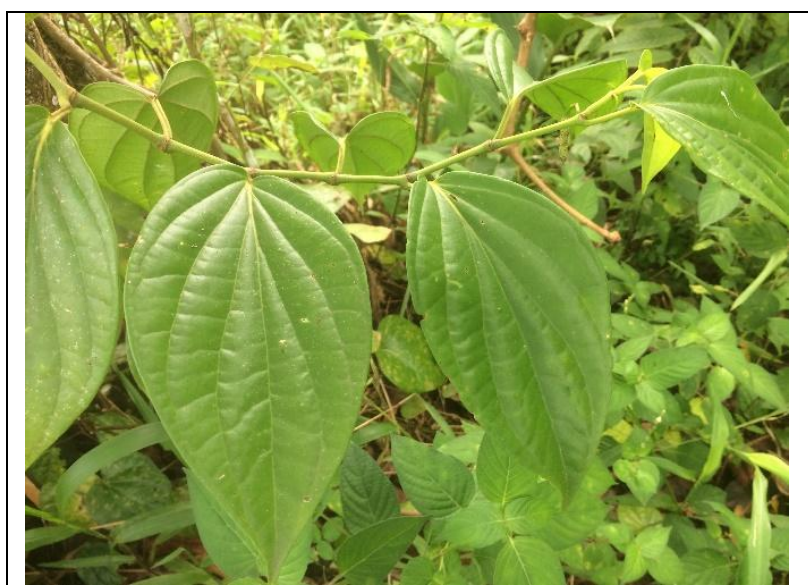

Fig.1 Leaf of Piper betle

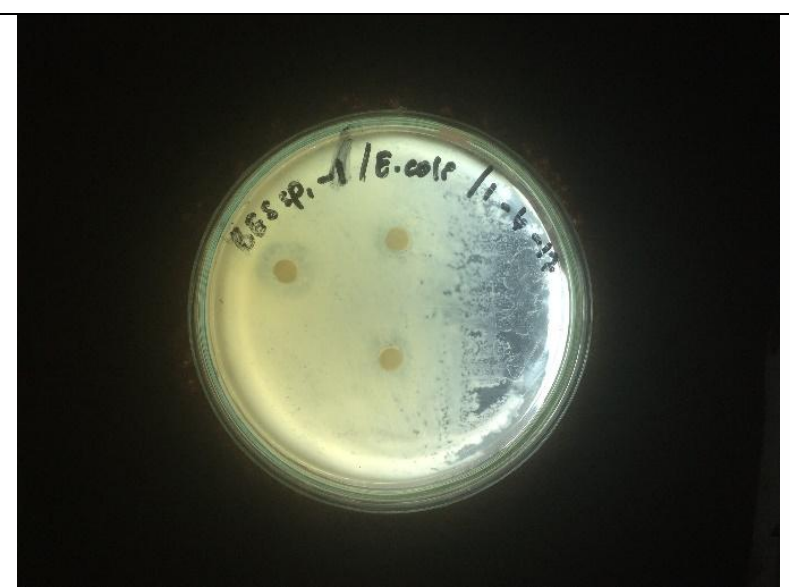

Fig.2 Inhibitory zone on E. coli

Table.1 Antibiotic test of isolates on E. coli and S. aureus

\begin{tabular}{ccl}
\hline \multirow{2}{*}{ Isolate code } & \multicolumn{2}{c}{ Inhibitory zone (mm) } \\
\cline { 2 - 2 } BES-1 & E. coli & S. aureus \\
BES-2 & 8.66 & 6.33 \\
BES-3 & 18.58 & 10.33 \\
BES-4 & 10.66 & 11.66 \\
BES-5 & - & 10.00 \\
BES-6 & 7.66 & - \\
BES-7 & 10.46 & 7.66 \\
BES-8 & - & 7.33 \\
BES-9 & 9.46 & 8.66 \\
BES-10 & - & 9.33 \\
BES-11 & - & 9.00 \\
\hline
\end{tabular}

Note: - (no inhibition zone is formed)

Exploration of betel endophytic microbes in the north-eastern part of the Indian state, found Muscodor albus which is a beta endophytic betel Piper nigrum that has strong antibiotic activity (Banerjee et al., 2014). Endophytic bacteria from betel $P$. colubrinum and $P$. nigrum are also antibiotic producers (Kulkarni et al., 2007). Fourteen green betelitic endophytic bacteria or $P$. betle live in Bogor district with the highest number of isolates from leaf organs with one potentially antibiotic-producing BS1 (Pseudomonas sp.) Isolates which can inhibit the growth of three pathogenic bacteria (Purwanto, 2014). Table 1 shows that eleven bacterial endophytic bacteria of green betel produce antibiotics with different inhibitory zones with each other, six isolates of endophytic bacteria with code BES-1, BES-2, BES-3, BES-6, BES-8 and BES 11 have zone inhibition against both test bacteria, it shows that the six isolates of endophytic bacteria are antibiotics that resulted are broad spectrum. Five other endophytic isolates are narrow spectrum, one isolate of BES-5 endophytic bacteria have antibiotic activity only in Gram negative bacteria $E$. coli and four isolates of endophytic bacteria BES-4, BES-7, BES-9 and BES-10 only on Gram bacteria positive $S$. aureus. Endophytic bacterial isolates BES-2 highest antibiotic producing zones, $18.58 \mathrm{~mm}$ against E. coli test bacteria, and BES-3 
endophytic bacterial isolates with the highest inhibitory zone $(11.66 \mathrm{~mm})$ in $S$. aureus test bacteria. Category of antibiotic activity strength based on inhibit zone, showed that five isolates of antibiotic-producing endophytic bacteria with strong category (BES-2, BES-3, BES-4, BES-6 and BES-11). Inhibitory diameter $10-20 \mathrm{~mm}$ including strong category, diameter more than $20 \mathrm{~mm}$ including very strong category and inhibition diameter between 5-10 $\mathrm{mm}$ belong to medium category (Davis and Stout, 1971).

\section{Acknowledgments}

Acknowledgments are presented to Faculty Mathematics and Natural Science, Andalas University which has provided research funding.

\section{References}

Ali, I., F.G. Khan, K.A. Suri, B.D. Gupta, N.K. Satti, P. Dutt, F. Afrin, G.N. Qazi and Khan, I.A. 2010. In vitro antifungal activity of hydroxychavicol isolated from Piper betle L. Annals of Clinical Microbiology and Antimicrobials. 9(7).

Arambewela, L., K.G.A., Kumaratunga and Dias, K. 2005. Studies on Piper betle of Srilanka. Journal Nature Science. 33, 133-139.

Banerjee, D., A. Pandey, M. Jana and Strobel, G. 2014. Muscodor albus MOW12 and endophyte of Piper nigrum L (Piperaceae) collected from North East India produces volatile antimicrobials. Indian Journal of Microbiology. 54(1): 27-32.

Djamaan, A., A. Agustien dan Yuni, D. 2012. Isolasi bakteri endofit dari tumbuhan surian (Toona sureni Blume Merr.) yang berpotensi sebagai penghasil antibakteri. Jurnal Bahan Alam Indonesia. 8(1).

Hoque, M.M, S. Rattila, M.A. Shishir, M.L.
Bari, Y. Inatsu and Kawamoto, S. 2011. Antibacterial Activity of Ethanol Extract of Betel Leaf (Piper betle L.) Against Some Food Borne Pathogens. Bangladesh Journal Microbiology. 28(2): 58-6.

Jalgaonwala, R.E., B.V. Mohite and Mahajan, R.T. 2010. Evaluation of endophytes for their antimicrobial activity from indigenous medicinal plants belonging to north Maharasthtra region India. International Journal on pharmaceutical and Biomedical Research. 1(5): 136141.

Kulkarni, A., S.M. Kelkar, M. Watre and Krishnamurthy. 2007. Characterization and control of endophytic bacterial in vitro culture of Piper spp., Taxus baccata subsp. Wallichiana and Withania somnifera. Canadian journal of Microbiology.53(1): 63-74.

Mano, H dan H., Morasaki. 2008. Endophyt bacteria in the rice plant. Microbes and Environment. 23(2): 109-117.

Melo, F.M.P, M.F Fiore, L.A.B de Mores, M.E.S. Stenico, S. Scramin, M.A.A Teixeira and de Melo I.S. 2009. Antifungal compound produced by the cassava endophyte Bacillus pumilus MAIIIM4A. Scientia Agricola. 66(5): 583-592.

Purwanto, U.M.S. 2014. Isolasi dan identifikasi senyawa antibakteri dari bakteri endofitik tanaman sirih hijau (Piper betle). Tesis, Pascasarjana, IPB, Bogor

Radji, M. 2005. Peranan bioteknologi dan mikroba endofit dalam pengembangan obat herbal. Majalah Ilmu Kefarmasian. 2(3): $113-126$.

Strobel, G.A and Daisy, B. 2003. Bioprospecting for Microbial Endophytes and Their Natural Products. Microbiology and Moleculer Biology Review. 67(4): 491-502.

Tanaka, M., H. Sukiman, M. Takebayashii, K. 
Saitoi,M. Suto, T.K. Prana, M.S. Prana and Tomitai, F. 1999. Isolation, screening and phylogenetics identification of endophytes from plants in Hokkaido Japan and Java Indonesia, Microbes and Environments. 14(4): 237-241.

Zinniel, D.K, P. Lambrecht, N.B. Harris, Z.
Feng, D. Kuczmarski, P. Higley, C.A. Ishimaru, A. Arunakumari, R.G. Barletta and Vidaver, A.K. 2002. Isolation and characterization of endophytic colonizing bacteria from agronomic crops and prairie plant. Applied Environmental Microbiology. 68(5): 2198-2208.

\section{How to cite this article:}

Anthoni Agustien, Putra Santoso, Nespy Permata Sari, Fathya Annisa, Nasril Nasir, Yetria Rilda and Akmal Djamaan. 2017. Screening of Endophyte Piper betle Bacteria from the Forests of HPPB University Andalas as Antibiotics Producer. Int.J.Curr.Microbiol.App.Sci. 6(12): 3970-3975. doi: https://doi.org/10.20546/ijcmas.2017.612.457 